Marcin Życzkowski ${ }^{1}$, Katarzyna Nabrdalik², Hanna Kwiendacz ${ }^{2}$, Diana Nabrdalik-Leśniak ${ }^{3}$, Janusz Gumprecht ${ }^{2}$

${ }^{1}$ School of Medicine with the Division of Dentistry in Zabrze, Department of Urology, Medical University of Silesia

${ }^{2}$ School of Medicine with the Division of Dentistry in Zabrze, Department of Internal Medicine, Diabetology and Nephrology,

Medical University of Silesia

${ }^{3}$ Department of Anaesthesiology and Intensive Critical Care, Municipal Hospital in Zabrze

\title{
Alprostadil in cream - a new option of treating erectile dysfunctions in diabetic patients
}

\section{ABSTRACT}

Diabetes mellitus is a risk factor for many urological complications, with the most frequent one in men, erectile dysfunction, occurring in patients with diabetes three times more often than in men with normal glucose tolerance. Diabetes contributes to erectile dysfunction through endothelial dysfunction, neuropathy, structural and functional dysfunction of cavernous bodies' smooth muscles and hormonal disorders. Alprostadil is a synthetic form of Prostaglandin E1, which directly affects arterial smooth muscles and causes vasodilatation. Besides being administrated deeply into the urethra and via injections into cavernous bodies, it might be used as a cream, which is rapidly and almost entirely absorbed into corpus spongiosum and cavernous bodies. It might be used as a first-line treatment for patients who have contraindications for PDE5 inhibitors or prefer topical application of the drug and as a second-line treatment in case of intolerance or no response to PDE5i, also for more complicated clinical cases, often occurring in diabetes. Alprostadil is administrated into the external urethral meatus 5-30 minutes before sexual intercourse; a complete erection appears in 10-12 minutes and lasts 1-2 hours. Due to

Address for correspondence:

dr n. med. Katarzyna Nabrdalik

Wydział Lekarski z Oddziałem Lekarsko-Dentystycznym w Zabrzu

Katedra i Klinika Chorób Wewnętrznych, Diabetologii i Nefrologii

Śląski Uniwersytet Medyczny

e-mail:knabradlik@yahoo.com

Translation: GROY Translations

Clinical Diabetology 2017, 6, 2, 70-75

DOI: $10.5603 /$ DK.2017.0012

Received: 16.03.2017

Accepted: 07.06.2017 lack of systemic effects, alprostadil in cream is safe and well tolerated, moreover, it does not interact with intake of food and alcohol. The advanced and effective therapy of erectile dysfunctions, which is alprostadil, helps to improve the quality of life in patients with diabetes. (Clin Diabetol 2017; 6, 2: 70-75)

Key words: diabetes mellitus, erectile dysfunction, alprostadil

\section{Introduction}

Diabetes mellitus (DM) is a risk factor for many urological complications. The relationship between DM type 2 and the growing incidence of cancers of the genitourinary system (prostate cancer, bladder cancer, renal cell cancer), urinary tract infections, kidney stones or androgen deficiency has been proven. The most common urological complication occurring in patients with diabetes is erectile dysfunction (ED) defined as the inability to develop or maintain an erection of the penis sufficient for satisfactory sexual intercourse [1]. It is estimated that in the US erectile dysfunction affects approx. 12 million men [2]. The epidemic growth in the prevalence of diabetes in the world can cause an increase in the number of patients prone to suffer from sexual sphere disorders, primarily from ED [3, 4]. The prevalence of ED in male population suffering from diabetes is estimated at 30-90\% [4-6]. Similarly, approximately $19.5 \%$ of men who visit an urologist due to ED suffer from diabetes [7]. The Massachusetts Aging Study has shown that ED is three times more common in the diabetic population compared to men with normal glucose tolerance. The prevalence of ED 
Table 1. The stages of erectile dysfunction treatment

\begin{tabular}{ll}
\hline Stage of therapy & Method of treatment \\
\hline First-line treatment & $\begin{array}{l}\text { Oral phosphodiesterase type 5 } \\
\text { inhibitors (PDE5i) }\end{array}$ \\
Second-line treatment & $\begin{array}{l}\text { Alprostadil in injections to cavernous } \\
\text { bodies, vacuum devices }\end{array}$ \\
Third-line treatment & $\begin{array}{l}\text { Surgical penile prosthesis } \\
\text { implantation }\end{array}$ \\
\hline
\end{tabular}

in diabetes increases with age, duration of disease and the deterioration of glycemic control, and is greater in patients with type 2 diabetes compared to patients with type 1 diabetes $[8,9]$. It was shown that there is a relation between ED and the increased risk of cardiovascular diseases, especially in men with metabolic syndrome [2]. Not only can ED appear in patients with risk factors of coronary heart disease and peripheral arterial disease, but may also precede the occurrence of cardiovascular disease $[10,11]$. This two-way relationship is due to the shared risk factors of arteriosclerotic cardiovascular disease both for ED and cardiovascular diseases [2, 12]. Early diagnosis of ED in patients with diabetes mellitus can help to prevent organic and emotional disorders in these men and help to identify cardiovascular risk factors. Screening for sexual dysfunction should become part of routine diabetes care [13]. Glycaemic control optimisation, treatment of accompanying disorders and lifestyle changes are the basis for therapeutic procedure in diabetic patients $[4,5,8,11]$. Pharmacological treatment is traditionally based on oral phosphodiesterase type 5 inhibitors (PDE5i), which is the first-line treatment, and if it is not effective, alprostadil is used for cavernous injection and vacuum devices (second-line treatment) as well as surgical procedures involving implantation of various types of penile prostheses (third-line treatment) (Tab. 1) $[2,5,6,8,14,15]$. This article will outline the advantages of using alprostadil as a cream for topical use as an effective treatment of erectile dysfunction in diabetic patients.

\section{Mechanism of penile erection}

Erectile function is associated with relaxing the smooth muscle of cavernous bodies resulting in the relaxation of arteries and trabeculae of cavernous bodies, and consequently in an increased flow of arterial blood to the recesses of penile cavernous bodies, and then in an activation of veno-occlusive mechanism (compression of the penile venous system into the tunica albuginea) and erection. The relaxation of the smooth muscle of cavernous bodies is a result of the decrease of the cytoplasmic concentration of the calcium ions, which is predominantly caused by the production of cyclic guanosine monophosphate (cGMP) in the smooth muscle under the influence of nitric oxide, which has an effect of the enzymatic cascade associated with protein kinase $\mathrm{G}$. The decrease of the concentration of calcium ions, and, therefore, the relaxation of the smooth muscle of cavernous bodies of the phallus and the erection in the cells, may also be caused by the production increase in another transmitter - cyclic adenosine monophosphate (cAMP). The increase in CAMP production is stimulated by the activation of the $\mathrm{PGE}_{1}$ receptors on the surfaces of the smooth muscles [12, 16-18].

\section{Risk factors of erectile dysfunction incidence}

The erection is a vascular and nervous phenomenon influenced by hormones; therefore, negative factors that affect each of the above-mentioned elements may lead to erectile dysfunction incidence. The most common causes of erectile dysfunctions are organic factors $(80 \%)$, among which dominate those that impair the flow of the adequate blood amount to the cavernous bodies of the phallus, namely cardiovascular diseases, diabetes mellitus, hypercholesterolemia, hypertension, metabolic syndrome, smoking and obesity $[2,12,19]$. Further, the risk factors of erectile dysfunctions include also diseases of the genitourinary system, lack of testosterone, sleep apnoea, some medications (neuroleptics, antidepressants, benzodiazepines, anti-androgens, diuretics, sympatholytics, beta blockers, calcium blockers) and radical treatment of prostate cancer - both chirurgical and radiotherapy $[2,20,21]$. The remaining $20 \%$ of the erectile dysfunction cases are caused by psychological and psychiatric issues [22].

Diabetes mellitus contributes to the erectile dysfunction incidence as a result of the endothelial dysfunction, peripheral neuropathy, structural and function dysfunction of the smooth muscles of cavernous bodies and hormonal dysfunctions [5, 23]. Importantly, a common incidence of sexual dysfunctions, usually erectile dysfunctions, has also been confirmed in men newly diagnosed with diabetes mellitus [13].

\section{Treatment of erectile dysfunctions in diabetic patients}

The pathophysiology and treatment of erectile dysfunctions in patients with diabetes significantly differ from those in patients with normal carbohydrate metabolism. Erectile dysfunctions in diabetic patients have a multifactorial etiology; they are more severe and more resistant to treatment than in the case of general 
population $[4,8,11]$. Moreover, in case of patients with type 2 diabetes, more severe erectile dysfunctions occur in patients with a coexisting vitamin $D$ deficiency [24]. Furukawa et al. showed a significant, independent correlation between the sedentary lifestyle with the incidence of erectile dysfunctions in men suffering from diabetes [25]. In experimental studies conducted on the animal model, Matsui et al. showed a reduction in the expression of genes for NTF-3 (neurotrophic factor 3), NGF (nerve growth factor), GCLDNF (glial cell linederived neurotrophic factor) and BDNF (brain-derived neurotrophic factor) within the major pelvic ganglia within 5 weeks after the induction of type 2 diabetes, were accompanied by significant erectile dysfunctions. The authors suggest that erectile dysfunctions can be prevented through the supplementation of neurotrophic factors in the early stages of type 2 diabetes [26].

Diabetic patients with erectile dysfunctions are advised to stop smoking cigarettes, exercise regularly, lose weight and improve blood glucose control and to improve hypertension and lipid disorders management $[4,5,8,11]$

Treatment of erectile dysfunction is divided into three categories: oral phosphodiesterase type 5 inhibitors (PDE5i) constituting first-line treatment, alprostadil in injections to cavernous bodies and vacuums, which are the second choice options, as well as third-line treatment which encompasses the surgery with an implantation of penile prostheses of various kinds [2, $5,6,8,14,15]$

It is worth noting that hypogonadism which often coexists with diabetes should also be diagnosed and treated [4]. The treatment usually requires maximum doses of PDE5 inhibitors. In patients who do not respond to the first-line treatment or in case of whom such a treatment is contraindicated, it is possible to use prostaglandin administered into the urethra, injections to the cavernous bodies, vacuum devices or penile prostheses $[4,5,14,15]$. Currently, there are no studies confirming the higher efficacy and safety of any of the PDE5 inhibitors. It should be kept in mind that all treatment options have their advantages and disadvantages and their efficacy differ [15]. Substances supporting the treatment also include alpha-lipoic acid and benfotiamine [27-29].

Zhang et al. compared the efficacy and safety of intravenous administration of $60 \mathrm{mg}$ of alprostadil in conjunction with $600 \mathrm{mg}$ of alpha-lipoic acid to oral administration of $5 \mathrm{mg}$ of tadalafil once a day for 2 weeks in patients with erectile dysfunctions and DM2. The effectiveness of alprostadil was significantly higher in relation to tadalafil $(p<0.05)$, with a smaller percentage of side effects $(7.5 \%$ vs. $13.9 \%, p<0.05)$ [28].

\section{Alprostadil}

Alprostadil is a synthetic form of prostaglandin $\mathrm{E}_{1}\left(\mathrm{PGE}_{1}\right)$ marked chemically as: $(11 \alpha, 13 \mathrm{E}, 15 \mathrm{~S})-11$, 15-dihydroxy-9-oxoprost-13-en-1-oic acid, with the molecular formula $\mathrm{C}_{20} \mathrm{H}_{34} \mathrm{O}_{5}$ and a molecular weight of $354.48 \mathrm{kDa}$, which causes a vasodilation due to its direct effect on smooth muscles of arteries, which is used, inter alia, for the treatment of erectile dysfunctions $[12,30]$. Alprostadil was used to treat erectile dysfunctions for the first time by Ishii and his colleagues in 1986 [31]. This led to the introduction and dissemination of alprostadil in the form of injections to the cavernous bodies of the penis and in the form of a gel administered into the urethra. Despite the fact that injections of alprostadil to cavernous bodies and deep administration of alprostadil to the urethra are extremely effective, they usually become a source of discomfort and stress for the patient and they are associated with the occurrence of side effects which are the result of systemic effects of this drug.

\section{Alprostadil in cream}

In the process of finding a solution to the abovementioned problems, an agent containing $300 \mu \mathrm{g}$ of alprostadil in $100 \mathrm{mg}$ of cream was developed. It should be administrated topically into the external urethral meatus. The development of a new form of $300 \mu \mathrm{g}$ alprostadil administered in the form of cream was possible due to the use of the substance increasing drug penetration $-2.5 \%$ of dodecyl-2-N,N-dimethylaminopropionate hydrochloride (DDAIP HCL). The excipient temporarily relaxes close connections between epithelial cells, which facilitates the penetration of the drug directly at the site of administration. An extremely important feature of DDAIP HCL is the fact that its molecules are biodegradable, non-toxic and easily metabolized [12, 32]. Thanks to the use of the substance increasing local penetration of alprostadil in cream, the drug is very quickly and almost completely absorbed through collateral vessels into the corpus spongiosum and cavernous bodies. This was confirmed in studies with the use of radiotracer, where up to $98 \%$ of the administered dose remained in the navicular fossa of urethra and the hemodynamic effect in the penis did not differ from the one obtained through the injection [32, 33]. Moreover, the administration of alprostadil in cream was associated with the lack of, or the occurrence of very low concentrations of, $\mathrm{PGE}_{1}$ and its metabolites in plasma, which suggests that the drug is not absorbed at all or is minimally absorbed into the cardiovascular system [32]. As a result, aplrostadil, which is well known for its effectiveness 
in the treatment of erectile dysfunctions, can be used in men in a non-invasive way, and its administration is not associated with the occurrence of systemic side effects [30, 33-35]. According to the recommendations of the group of experts concerning the treatment of alprostadil in cream in patients with erectile dysfunctions, such a procedure can be used as the first-line treatment for patients who prefer the topical application of the drug and those who do not want to ingest phosphodiesterase type 5 inhibitors (PDE5i) or who cannot take them due to certain contraindications, e.g. patients taking nitrates, patients suffering from heart diseases, diabetes, hypertension, patients for whom there are no contraindications for sexual activity, and patients after radical removal of prostate due to cancer. Alprostadil in cream is used as the secondline treatment in patients who do not respond to the treatment with PDE5i, patients who do not tolerate the treatment with PDE5i or men who want to avoid injections of alprostadil injections to cavernous bodies [12]. Alprostadil in cream is available in the dosage strength of $300 \mu \mathrm{g}$ of alprostadil in $100 \mathrm{mg}$ of cream. The drug should be administered into the external urethral meatus 5 to 30 minutes before the planned intercourse. The application into the urethra is facilitated by the AccuDose system [12]. The drug begins to take effect 5 to 30 minutes after the application whereas full erection is usually obtained within 10-12 minutes and maintained for about 1-2 hours [36]. The maximum recommended frequency of use of alprostadil in cream is 2-3 applications a week, but it cannot be used at intervals shorter than 24 hours. No interactions of alprostadil in cream with alcohol or food were observed and the rapid metabolism of the drug excludes its systemic toxicity. The application of alprostadil in cream in the treatment of men with erectile dysfunctions is contraindicated in patients who are advised to refrain from any sexual activity (i.e. in patients with unstable cardiovascular or cerebrovascular diseases; with orthostatic hypotension, myocardial infarction, syncope; urethritis or balanitis; with anatomical abnormalities of the penis (severe form of hypospadias, curvature of the penis); with conditions that can be associated with the predisposition to priapism (sickle cell anaemia or being the carrier of the gene of sickle cell anaemia, thrombocytopenia, polycythemia, multiple myeloma or leukaemia); in patients susceptible to venous thrombosis or in patients with hyperviscosity syndrome and diagnosed increased risk of priapism; with diagnosed hypersensitivity to alprostadil or any of the drug ingredients and in men whose female partners are planning to become pregnant) [35].
Alprostadil in cream is safe and well tolerated by patients. The vast majority (97\%) of side effects observed in studies was characterised by low intensity and short duration not exceeding 60 minutes [34-40]. Almost all the side effects limited to the site of administration of the cream and they mostly included: burning of the penis $(23 \%)$, redness of the glans $(11.3 \%)$, and balanitis (4.6\%) [38]. About $2 \%$ of sexual female partners of men using alprostadil in cream without a condom reported mild vaginal burning that disappeared within an hour. The risk of prolonged erections and priapism was small and concerned respectively $1.3 \%$ and $0.4 \%$ of men. Systemic side effects in patients using alprostadil in cream are very rare. Dizziness and loss of consciousness were only observed in $0.5 \%$ of the cases. Phase 2 and 3 trials proved the effectiveness of the preparation when it was used in cases that are difficult to treat, i.e. in men with diabetes, metabolic syndrome, after radical prostatectomy and after unsuccessful treatment with sildenafil [38]. Moreover, alprostadil in cream was also effective and safe in patients with hypertension, taking nitrates or alpha inhibitors [38]. In general, in the phase 2 and 3 trials, alprostadil in cream administered into the external urethral meatus resulted in an adequate erection in $74-83 \%$ of patients $[38,41]$. The efficacy of the preparation was assessed in both short-term and long-term studies. The efficacy of alprostadil in cream administered initially for 4 weeks at the dose of $200 \mu \mathrm{g}$ and then at the modified dose of up to $100 \mu \mathrm{g}, 200 \mu \mathrm{g}$ or $300 \mu \mathrm{g}$ depending on the response of the patient to the treatment which was continued twice a week for up to 9 months was assessed in the open-label, multicentre study [39]. $75 \%$ of men chose the dose of $300 \mu \mathrm{g}$ as the final dose, which was administered every 4-7 days. According to the results obtained in the questionnaire of the International Index of Erectile Function (IIEF), a statistically significant improvement of erectile dysfunctions was obtained for the dose of $300 \mu \mathrm{g}(\mathrm{p}<0.001)$ and as a result, severe-moderate erectile dysfunctions before treatment changed to moderate-minimal after treatment. Moreover, a large increase in the number of patients giving positive answers to questions 2 and 3 of the Sexual Encounter Profile (SEP) questionnaire, i.e. SEP2 - Were you able to insert your penis into your female partner's vagina?, SEP3 - Did the erection allowed you to have a satisfactory sexual intercourse?, was observed in the group of men taking the dose of $300 \mu \mathrm{g}$. Accordingly $80.3 \%$ and $61.1 \%$ of men gave positive answers to questions SEP2 and SEP3 at the end of the study, whereas during the first appointment (after taking $200 \mu \mathrm{g}$ of alprostadil for 30 days), this percentage was $65.8 \%$ and $46.9 \%$, respectively [39]. 


\section{Summary}

Due to the increasing incidence of diabetes and the significant co-incidence of erectile dysfunctions which have a great impact on the quality of life, it is important to draw attention to modern and effective treatment methods of this condition. Alprostadil in cream administered into the external urethral meatus is an effective therapeutic option in patients with erectile dysfunctions. It can be used for the pharmacological first-line treatment in men with erectile dysfunctions and for the second-line treatment in patients with no response to or intolerance of PDE5i as well as in difficult cases, e.g. underlying diabetes. The application of the substance facilitating the absorption of the drug directly at the site of administration gives effects in a short time after its application irrespective of causes of erectile dysfunctions and without any interactions with food and alcohol. Alprostadil in cream can be safely used in patients taking nitrates, alpha inhibitors and other hypotensive drugs, because it does not cause any systemic side effects in them.

\section{REFERENCES}

1. Sayyid RK, Fleshner NE. Diabetes Mellitus Type 2: A Driving Force for Urological Complications. Trends Endocrinol Metab. 2016; 27(5): 249-261, doi: 10.1016/j.tem.2016.02.006, indexed in Pubmed: 26969242.

2. Rew KT, Heidelbaugh JJ. Erectile Dysfunction. Am Fam Physician. 2016; 94(10): 820-827, indexed in Pubmed: 27929275.

3. Isidro ML. Sexual dysfunction in men with type 2 diabetes. Postgrad Med J. 2012; 88(1037): 152-159, doi: 10.1136/postgradmedj-2011-130069, indexed in Pubmed: 22282735.

4. Malavige LS, Levy JC. Erectile dysfunction in diabetes mellitus. J Sex Med. 2009; 6(5): 1232-1247, doi: 10.1111/j.17436109.2008.01168.x, indexed in Pubmed: 19210706.

5. Hatzimouratidis K, Hatzichristou D. How to treat erectile dysfunction in men with diabetes: from pathophysiology to treatment. Curr Diab Rep. 2014; 14(11): 545, doi: 10.1007/s11892-014-0545-6, indexed in Pubmed: 25193347.

6. Price $D$, Hackett G. Management of erectile dysfunction in diabetes: an update for 2008. Curr Diab Rep. 2008; 8(6): 437-443, indexed in Pubmed: 18990299.

7. Mazzilli R, Elia J, Delfino M, et al. Prevalence of Diabetes Mellitus (DM) in a population of men affected by Erectile Dysfunction (ED). Clin Ter. 2015; 166(5): e317-e320, indexed in Pubmed: 26550816.

8. Basu A, Ryder REJ. New treatment options for erectile dysfunction in patients with diabetes mellitus. Drugs. 2004; 64(23): 2667-2688, indexed in Pubmed: 15537369.

9. Binmoammar TA, Hassounah S, Alsaad S, et al. The impact of poor glycaemic control on the prevalence of erectile dysfunction in men with type 2 diabetes mellitus: a systematic review. JRSM Open. 2016; 7(3): 2054270415622602, doi: 10.1177/2054270415622602, indexed in Pubmed: 26981254.

10. Hatzimouratidis K, Amar E, Eardley I, et al. Guidelines on Male Sexual Dysfunction: Erectile Dysfunction and Premature Ejaculation. European Urology. 2010; 57(5): 804-814, doi: 10.1016/j. eururo.2010.02.020.

11. Phé V, Rouprêt M. Erectile dysfunction and diabetes: a review of the current evidence-based medicine and a synthesis of the main available therapies. Diabetes Metab. 2012; 38(1):
1-13, doi: 10.1016/j.diabet.2011.09.003, indexed in Pubmed: 22056307.

12. Gołąbek T, et al. Zalecenia zespołu ekspertów dotyczące leczenia alprostadylem w kremie chorych z zaburzeniami wzwodu. Przegl Urol. 2016; 5: 34-39.

13. Corona G, Giorda CB, Cucinotta D, et al. Gruppo di studio SUBITO-DE. Sexual dysfunction at the onset of type 2 diabetes: the interplay of depression, hormonal and cardiovascular factors. J Sex Med. 2014; 11(8): 2065-2073, doi: 10.1111/jsm.12601, indexed in Pubmed: 25041930.

14. Porst $H$, Burnett $A$, Brock $G$, et al. ISSM Standards Committee for Sexual Medicine. SOP conservative (medical and mechanical) treatment of erectile dysfunction. J Sex Med. 2013; 10(1): 130-171, doi: 10.1111/jsm.12023, indexed in Pubmed: 23343170.

15. Moisidis K, Kalinderis N, Hatzimouratidis K, et al. A comparative review of the options for treatment of erectile dysfunction: which treatment for which patient? Drugs. 2005; 65(12): 1621-1650, indexed in Pubmed: 16060698.

16. Adaikan PG, Kottegoda SR, Ratnam SSA. possible role for prostaglandin E1 in human penile erection. Proceedings of the Second World Meeting on Impotence, Prague, Czechoslovakia. 1986; Abstract; 2: 6.

17. Palmer LS, Valcic M, Melman A, et al. Characterization of cyclic AMP accumulation in cultured human corpus cavernosum smooth muscle cells. J Urol. 1994; 152(4): 1308-1314, indexed in Pubmed: 8072124

18. Traish AM, Moreland RB, Gallant C, et al. G-protein-coupled receptor agonists augment adenylyl cyclase activity induced by forskolin in human corpus cavernosum smooth muscle cells. Recept Signal Transduct. 1997; 7(2): 121-132, indexed in Pubmed: 9392440.

19. Lewis RW, Fugl-Meyer KS, Corona G, et al. Epidemiology/ /risk factors of sexual dysfunction. J Sex Med. 2004; 1(1): 35-39, doi: 10.1111/j.1743-6109.2004.10106.x, indexed in Pubmed: 16422981.

20. Selvin E, Burnett AL, Platz EA. Prevalence and risk factors for erectile dysfunction in the US. Am J Med. 2007; 120(2): 151-157, doi: 10.1016/j.amjmed.2006.06.010, indexed in Pubmed: 17275456.

21. Buvat J, Maggi M, Gooren L, et al. Endocrine aspects of male sexual dysfunctions. J Sex Med. 2010; 7(4 Pt 2): 1627-1656, doi: 10.1111/j.1743-6109.2010.01780.x, indexed in Pubmed: 20388162.

22. McVary KT, et al. Sexual Dysfunction, in Harrison's Principles of Internal Medicine, Longo DL, , Editors. 2012, McGraw Hill.: 374-379.

23. Gandhi J, Dagur G, Warren K, et al. The Role of Sexual Dysfunction and Infertility on Reproductive Health in Diabetics: Pathogenesis, Evaluation, and Management. Curr Diabetes Rev. 2016 [Epub ahead of print], indexed in Pubmed: 27875946.

24. Caretta N, de Kreutzenberg SV, Valente U, et al. Hypovitaminosis $\mathrm{D}$ is associated with erectile dysfunction in type 2 diabetes. Endocrine. 2016; 53(3): 831-838, doi: 10.1007/s12020-015-0851-z, indexed in Pubmed: 26758995.

25. Furukawa S, Sakai T, Niiya T, et al. Self-reported sitting time and prevalence of erectile dysfunction in Japanese patients with type 2 diabetes mellitus: The Dogo Study. J Diabetes Complications. ; 2017;31(1):53-57., doi: DOI: 10.1016/j.jdiacomp.2016.10.011, indexed in Pubmed: PMID: 27836682.

26. Matsui H, Musicki B, Sopko NA, et al. Early-stage Type 2 Diabetes Mellitus Impairs Erectile Function and Neurite Outgrowth From the Major Pelvic Ganglion and Downregulates the Gene Expression of Neurotrophic Factors. Urology. 2017; 99: 287. e1-287.e7, doi: 10.1016/j.urology.2016.08.045, indexed in Pubmed: 27639791.

27. Hurdag C, Ozkara H, Citci S, et al. The effects of alpha-lipoic acid on nitric oxide synthetase dispersion in penile function in streptozotocin-induced diabetic rats. Int J Tissue React. 2005; 27(3): 145-150, indexed in Pubmed: 16372481. 
28. Zhang L, Zhang HY, Huang FC, et al. Study on the clinical value of alprostadil combined with $\alpha$-lipoic acid in treatment of type 2 diabetes mellitus patients with erectile dysfunction. Eur Rev Med Pharmacol Sci. 2016; 20(18): 3930-3933, indexed in Pubmed: 27735021.

29. Tjandra BS, Janknegt RA. Neurogenic impotence and lower urinary tract symptoms due to vitamin B1 deficiency in chronic alcoholism. J Urol. 1997; 157(3): 954-955, indexed in Pubmed: 9072614.

30. Becher E. Topical alprostadil cream for the treatment of erectile dysfunction. Expert Opin Pharmacother. 2004; 5(3): 623-632, doi: 10.1517/14656566.5.3.623, indexed in Pubmed: 15013930.

31. Ishii N, Watanabe $H$, Irisawa $C$, et al. [Studies on male sexual impotence. Report 18. Therapeutic trial with prostaglandin E1 for organic impotence]. Nihon Hinyokika Gakkai Zasshi. 1986; 77(6): 954-962, indexed in Pubmed: 3773397.

32. Beihn RM. Gamma scintigraphy measurement of the retention and migration of an erectile dysfunction topical formulation applied to the tip of the human male penis. Data on file at NexMed (USA), Inc.; Protocol No. NEXSCIN 2001-001; US IND No 53. ; 953: 2002.

33. Becher E, Borghi M, Momesso A. Montes De Oca L. Penile hemodynamic finding with a new topical formulation of alprostadil. J Urol 1998; 159 (Suppl2. ; 239(Abstract 915).

34. Yeager J, Beihn RM. Retention and migration of alprostadil cream applied topically to the glans meatus for erectile dysfunction. Int J Impot Res. 2005; 17(1): 91-95, doi: 10.1038/sj.ijir.3901285, indexed in Pubmed: 15538395.
35. http://pub.rejestrymedyczne.csioz.gov.pl/ProduktSzczegoly. aspx?id=35177.

36. Steidle C, Padma-Nathan H, Salem S, et al. Topical alprostadil cream for the treatment of erectile dysfunction: a combined analysis of the phase II program. Urology. 2002; 60(6): 1077-1082, indexed in Pubmed: 12475674.

37. Padma-Nathan $H$, Steidle $C$, Salem S, et al. The efficacy and safety of a topical alprostadil cream, Alprox-TD, for the treatment of erectile dysfunction: two phase 2 studies in mild-to-moderate and severe ED. Int J Impot Res. 2003; 15(1): 10-17, doi: 10.1038/ /sj.ijir.3900940, indexed in Pubmed: 12605235.

38. Padma-Nathan H, Yeager JL. An integrated analysis of alprostadil topical cream for the treatment of erectile dysfunction in 1732 patients. Urology. 2006; 68(2): 386-391, doi: 10.1016/j.urology.2006.02.027, indexed in Pubmed: 16904458.

39. Rooney M, Pfister W, Mahoney M, et al. Long-term, multicenter study of the safety and efficacy of topical alprostadil cream in male patients with erectile dysfunction. J Sex Med. 2009; 6(2): 520-534, doi: 10.1111/j.1743-6109.2008.01118.x, indexed in Pubmed: 19138370 .

40. Mulhall J, Porst H, Goldstein I, et al. Comparison of Vitaros efficacy and safety with short-term and long-term Use. ESSM-ISSM Berlin. 2013: Poster.

41. Moncada I, Cuzin B. Clinical efficacy and safety of Vitaros@/Virirec $($ (Alprostadil cream) for the treatment of erectile dysfunction. Urologia. 2015; 82(2): 84-92, doi: 10.5301/uro.5000116, indexed in Pubmed: 25744707. 